2-1-2021

\title{
Water Quality Engineering and Wastewater Treatment
}

\author{
Yung Tse Hung \\ Cleveland State University, y.hung@csuohio.edu \\ Hamidi Abdul Aziz \\ Universiti Sains Malaysia \\ Issam A. Al-Khatib \\ Birzeit University \\ Rehab O. Abdel Rahman \\ Atomic Energy Authority of Egypt \\ Mario G.R. Cora-Hernandez \\ University of Maryland University College
}

Follow this and additional works at: https://engagedscholarship.csuohio.edu/encee_facpub

Part of the Civil and Environmental Engineering Commons

How does access to this work benefit you? Let us know!

\section{Recommended Citation}

Hung, Yung Tse; Aziz, Hamidi Abdul; Al-Khatib, Issam A.; Abdel Rahman, Rehab O.; and Cora-Hernandez, Mario G.R., "Water Quality Engineering and Wastewater Treatment" (2021). Civil and Environmental Engineering Faculty Publications. 389.

https://engagedscholarship.csuohio.edu/encee_facpub/389

This Editorial is brought to you for free and open access by the Civil and Environmental Engineering at EngagedScholarship@CSU. It has been accepted for inclusion in Civil and Environmental Engineering Faculty Publications by an authorized administrator of EngagedScholarship@CSU. For more information, please contact library.es@csuohio.edu. 


\title{
Water Quality Engineering and Wastewater Treatment
}

\author{
Yung-Tse Hung ${ }^{1}\left(\mathbb{D}\right.$, Hamidi Abdul Aziz ${ }^{2,3, *} \mathbb{D}$, Issam A. Al-Khatib ${ }^{4}\left(\mathbb{D}\right.$, Rehab O. Abdel Rahman ${ }^{5}$ and \\ Mario GR Cora-Hernandez ${ }^{6}$
}

1 Department of Civil and Environmental Engineering, Cleveland State University, Cleveland, OH 44115, USA; y.hung@csuohio.edu

2 School of Civil Engineering, Engineering Campus, Universiti Sains Malaysia, Pulau Pinang 14300, Malaysia

3 Solid Waste Management Cluster, Engineering Campus, Universiti Sains Malaysia, Pulau Pinang 14300, Malaysia

4 Institute of Environmental and Water Studies, Faculty of Graduate Studies, Birzeit University, Birzeit P.O. Box 14, West Bank, Palestine; ikhatib@birzeit.edu

5 Hot Lab. \& Waste Manag. Center, Atomic Energy Authority of Egypt, Inshas, Cairo P.O. No. 13759, Egypt; alaarehab@yahoo.com

6 School of Undergraduate Studies, Sciences Program, University of Maryland University College, 3501 University Blvd East, Adelphi, MD 20783, USA; mariocora2000@yahoo.com

* Correspondence: cehamidi@usm.my

check for updates

Citation: Hung, Y.-T.; Abdul Aziz, H.; Al-Khatib, I.A.; Abdel Rahman, R.O.; Cora-Hernandez, M.G. Water Quality Engineering and Wastewater Treatment. Water 2021, 13, 330. https: / doi.org/10.3390/w13030330

Received: 13 January 2021

Accepted: 27 January 2021

Published: 29 January 2021

Publisher's Note: MDPI stays neutral with regard to jurisdictional claims in published maps and institutional affiliations.

Copyright: (c) 2021 by the authors. Licensee MDPI, Basel, Switzerland. This article is an open access article distributed under the terms and conditions of the Creative Commons Attribution (CC BY) license (https:// creativecommons.org/licenses/by/ $4.0 /)$.
Wastewater treatment is crucial to prevent environmental pollution. Wastewater sources include domestic households, municipal communities, or industrial activities. Wastewater that is discharged to the environment must be treated to prevent pollution to the environment. However, wastewater remains one of the major pollutants of our inland waterways. To satisfy the tighter regulatory requirements, the implementation of more advanced design in wastewater treatment technologies is required. Treatment of wastewater usually includes physical, chemical, and biological processes. Today's wastewater treatments are much more technologically advanced than they were in previous years. Many centralized mechanized treatments are run via a computer system, and they are run more efficiently. In this Special Issue, we attempted to discuss and address the state-of-the-art of wastewater quality, treatment, and its management.

This special issue is composed of 18 innovative papers and reviews that address water quality engineering and wastewater treatment. The study areas in which these topics are developed include wastewater treatment from acid mine drainage, municipal wastewater, landfill leachate, groundwater, greywater, industrial wastewater, and urban wastewater. The issue also covers the degradation mechanism of one of the nonsteroidal anti-inflammatory medications most widely used, diclofenac (DIC), by an $\mathrm{MnO}_{2}$ catalyst. In addition, the issue also present papers on eutrophication, wastewater de-nitrification, micropollutants treatment, nanoparticles application in wastewater treatment, and a paper each for a new ecotoxicity measuring tool by using optical camera and inactivation and loss of solar irradiation infectivity of Enterovirus 70 . The three review papers include the use of natural polymers' modification in wastewater treatment of toxicant dye compounds, metallic iron for environmental remediation using metallic iron $\left(\mathrm{Fe}^{0}\right)$ as a reactive agent, and the utilization of ionizing radiation in wastewater purification.

The papers in the Special Issue are summarized as follows:

Biological sulfate reduction (BSR) has been recognized as a favorable option for the purification of acid mine drainage. The influence of temperature, $\mathrm{pH}$, and hydraulic retention time (HRT) on BSR has been examined in downflow mode packed bed reactors [1]. They concluded that HRT and temperature had a powerful interaction; however, the effect of $\mathrm{pH}$ was negligible. In addition, due to higher flow rates, a decrease in HRT had a positive effect on the rate of sulfate reduction. On the other hand, it had a deleterious effect on the performance of sulfate remediation, most probably caused by substrates being washed out.

During the wastewater treatment process, Lange et al. [2] examined the behavior of nanoparticles $\mathrm{nTiO}_{2}$ and $\mathrm{nCeO}_{2}$ in wastewater treatment modes (at lab-scale) to model 
the mass flow of anthropogenic nanoparticles (NP) in the wastewater treatment process. The findings indicate that $\mathrm{nTiO}_{2}$ and $\mathrm{nCeO}_{2}$ are adsorbed to at least $90 \%$ of the sludge. In addition, the findings show that there are steps that entail a shift in the shape of the NP in the effluent during the passage of the treatment method, as the NP in the effluent was found to be partly lesser than in the added solution. This statement was denoted, especially for $\mathrm{nCeO}_{2}$, and may be caused by dissolution action or higher particles sedimentation during the transit of the treatment procedure.

One of the water species used to assess ecotoxicity is Lemna minor (Lesser duckweedAngiospermae, Lemnaceae). Haffner et al. [3] tested a cheaper process for a Lemna minor bioassay assessment by computer and machine vision. The aim was to use a digital camera and a framework software instrument to design a methodology for image analysis. In this paper, instead of counting individual leaves, they suggested using computer vision to calculate and compare the area covered by the leaves and compared the modern procedure with the ordinary one. They concluded that the toxic effect was more meaningful when examining the leaf area instead of the number of leaves. In addition, errors resulting from a human element are removed using the computer vision-based approach during leaf counting.

The degradation of Diclofenac (DIC) by tunnel-structured $\mathrm{MnO}_{2}$ based on solution $\mathrm{pH}$ with excellent oxidative and catalytic capacities was investigated by Hu et al. [4]. DIC can be effectively oxidized in an acidic medium by $\gamma-\mathrm{MnO}_{2}$, and at alkaline and neutral conditions, the removal rate decreased significantly. The developed model could successfully match the kinetics of DIC degradation and demonstrated the regulation of electron transfer at acidic environments and the complex precursor structure control mechanism within neutral to alkaline environments, by which the $\mathrm{pH}$ level corresponds precisely to the percentage of distribution of ionized DIC species for two mechanisms. 5-iminoquinone DIC, hydroxylDIC, and 2,6-dichloro-N-o-tolylbenzenamine were the major oxidation products with a strong dynamic hydroxylation route in the tunnel-structured Mn-oxide.

The ability of Moringa oleifera (MO) seeds as a coagulant to remove turbidity, biochemical oxygen demand (BOD), and chemical oxygen demand (COD) from urban wastewater was investigated by Adelodun et al. [5]. Their outcomes indicated that employing a MO dose of $150 \mathrm{mg} / \mathrm{L}$, the maximal reduction in turbidity, BOD, and COD was $94 \%, 69 \%$, and $58 \%$, respectively. They recommended this low-cost and natural MO coagulant be used for the safe removal of turbidity, BOD, and COD from urban wastewater.

Remediation of metal contamination from groundwater and greywater supplies in Riyadh, Saudi Arabia, was investigated by Alomar et al. [6]. Ultrasonic power before adsorption was also explored to measure the distribution of renewable carbon from mixed waste sources (RC-MWS) as an adsorbent and to improve the water treatment system. From the actual water samples under study, the renewable carbon adsorbent exhibited a greater adsorption potential of $\mathrm{Pb}(\mathrm{II}), \mathrm{Zn}(\mathrm{II}), \mathrm{Cu}(\mathrm{II})$, and $\mathrm{Fe}(\mathrm{II})$. The increased adsorption method demonstrated the greatest efficiency at a $\mathrm{pH}$ of 6 , room temperature, and $60 \mathrm{~min}$ contact time.

Thaher et al. [7] examined the local population's views of On-site GreyWater Treatment Plants (GWTPs) for rural community wastewater management in Palestine. They found that the reasons for adopting GWTPs included the use of GWTPs in irrigation, the reduction in the frequency and financial effects of cesspit discharges, water scarcity, the reduction in possible risks of groundwater contamination, the decrease in the water bill and improved hygiene, and funds availability for their use. The reuse of treated greywater in irrigation has also been approved by the Islamic religion. In GWTP management, women play a major role. The majority $(70 \%)$ of GWTP recipients were pleased. Operation and maintenance took little effort, with just a mean of $0.4 \mathrm{~h}$ of working per week. Odor pollution, insect infestation, implementing agency limitations in doing follow-up and monitoring, system failures triggered by insufficient beneficiary expertise in service and maintenance and deficiency of system awareness, and health issues and doubts concerning the quality of crops irrigated by treated greywater were among the obstacles to the implementation of 
the GWTPs. In rural areas, house on-site greywater management systems were acceptable; therefore, an adequate system is needed to deal with wastewater and replace cesspits and their hazardous environmental, groundwater, and public health implications.

Alkhudhiri et al. [8] used air gap membrane distillation (AGMD) to remove heavy metals from synthetic industrial wastewater specimens comprising mercury $(\mathrm{Hg})$, arsenic $(\mathrm{As})$, and lead $(\mathrm{Pb})$. The results demonstrated that TF200 and TF450 showed excellent reductions at a wide range of concentrations, which exceeded $96 \%$ for heavy metal ions. Furthermore, the $\mathrm{pH}$ value did not have a major impact on the efficiency of metal reduction. Energy usage was controlled at diverse pore sizes of the membrane, and it was identified to be almost unrelated to the pore size of the membrane and class of metal.

In an urban river in North China, Bai et al. [9] tested various sequentially constructed wetlands for contaminated water. From April to October 2016, the monitoring results showed that chemical oxygen (COD), ammonia nitrogen $\left(\mathrm{NH}_{4}-\mathrm{N}\right)$, total nitrogen (TN), total phosphate (TP), and suspended solids (SS) could be efficiently removed by multiple wetland ecosystems at average elimination rates of $75 \%, 81 \%, 71 \%, 78 \%$, and $92 \%$, respectively. Of all methods, the floating-bed wetlands exhibited the highest elimination rate of SS $(80 \%)$, which could effectively stop the blockage of sub-surface flow wetlands. The $\mathrm{NH}_{4}-\mathrm{N}, \mathrm{TN}$, and TP were efficiently eliminated by the sub-surface flow wetland, and the contribution rates were $79 \%, 65 \%$, and $82 \%$. The surface wetland flow will further clean the $\mathrm{TN}$, and the reduction in the TN will approach $23 \%$. The general expense of this investment in environmental engineering was $\$ 12,000$. Building and operation costs were $\$ 120$ and $\$ 0.02$ per tonne of wastewater.

The influence of inundation and eutrophication on the production of the Wedelia Trilobata (WT) trait over its congener native Wedelia Chinensis was investigated by Azeem et al. [10] to understand the terrestrial plant reaction when affected by a riparian zone. It was found that both species survive and grow well under submergence and eutrophication, but high submergence and eutrophication provide superior conditions for WT to flourish. Environmental modeling suggested that artificial disruption and climate change, which was approximately $1 / 3$ to $1 / 5$ and $1 / 6$ to $1 / 3$ of traditional sewage treatment, will ensure submergence and eutrophication, respectively.

Hamid et al. [11] investigated the pattern of a unique zeolite supplemented by the electrocoagulation method (ZAEP) by an aluminum electrode to treat high-strength ammonia concentration $(3471 \mathrm{mg} / \mathrm{L})$ from saline $(15.36 \mathrm{ppt})$ landfill leachate in nature. It was observed that up to $71 \%$ of ammonia was removed, with the ideal working treatment operation as follows: $105 \mathrm{~g} / \mathrm{L}$ zeolite dosage, the current density of $600 \mathrm{~A} / \mathrm{m}^{2}, 60 \mathrm{~min}$ electrolysis duration, and $\mathrm{pH}$ 8.20. The results indicate that ZAEP treatment is a sustainable solution for concentration landfill leachate without the use of auxiliary salinity.

A laboratory-scale aerobic-methane oxidation bioreactor (MOB)-anoxic device was developed by Le et al. [12], which combined MOB with the aerobic-anoxic de-nitrification method and assessed its possibility to eliminate nitrogen in wastewater treatment plants (WWTPs). Based on three months of continuous running employing real wastewater, the total nitrogen elimination was $76 \%$, close to the performance of a tertiary-advanced WWTP, and the total phosphorus reduction reached $84 \%$.

Mojiri et al. [13] based their research on the treatment of pharmaceuticals micropollutant. The goal was to eliminate diclofenac (DCF), ibuprofen (IBP), and naproxen (NPX) from the water by cross-linked magnetic chitosan/activated biochar (CMCAB). Two point four one milligram per liter (96\%) of DCF, $2.47 \mathrm{mg} / \mathrm{L}$ (99\%) of IBP, and $2.38 \mathrm{mg} / \mathrm{L}$ $(95 \%)$ of NPX were eliminated at a $\mathrm{pH}$ of 6.0 and an initial micropollutant (MP) concentration of $2.5 \mathrm{mg} / \mathrm{L}$. Eventually, desorption experiments demonstrated that cross-linked magnetic chitosan/activated biochar could be used for a minimum of eight adsorptiondesorption series.

Solar Irradiation Inactivation and Loss of Enterovirus 70 Infectivity Enterovirus 70 (EV70) is a novel viral pathogen that could be present in the final effluent. For this, solar irradiation as a low-cost natural disinfection technique was studied by Jumat and Hong [14] 
to alleviate possible concerns. EV70 reduced its infectivity in the presence of sunlight in PBS, effluent, and chlorinated effluent, respectively, by $1.7 \mathrm{log}, 1.0 \mathrm{log}$, and $1.3 \mathrm{log}$. The decrease in EV70 infectivity was consistent with a decrease in the viral binding capacity of Vero cells. Furthermore, a genome sequencing analysis exhibited five non-synonymous nucleotide displacements in irradiated viruses following 10 days of infection in Vero cells, leading to amino acid substitutions.

Aziz et al. [15] used a mixture of polyaluminium chloride (PACl) as a coagulant and Dimocarpus longan seed powder (LSP) as a coagulant to help treat landfill leachate by introducing a coagulation-flocculation process. The highest reductions in COD, SS, and color were $69 \%, 100 \%$, and $99 \%$, respectively, when LSP was employed as a coagulant aid with PACl. The PACl dose was reduced from 5 to $2.75 \mathrm{~g} / \mathrm{L}$ when LSP was applied as a coagulant aid. The cost estimate for using $\mathrm{PACl}$ as a sole coagulant and using LSP as a flocculant indicated a decrease of about $40 \%$ in the cost of using just $\mathrm{PACl}$.

Ishak et al. [16] reviewed the use of diverse forms of natural and modified polymers to remove wastewater toxicant dyes discharged by the dye industry. Even though modified polymers are favored for dye treatment because of their biodegradability and non-toxic nature, high amounts of polymers are needed, which is expensive. To treat dyes from wastewater, surface-modified polymers are more effective. A study of 80 recently published research work showed that modified polymers have an excellent capacity to eliminate dye and, therefore, have high applicability in the treatment of industrial wastewater.

Hu et al. [17] performed a significant review of the abundant literature on the environmental remediation and water purification metallic iron $\left(\mathrm{Fe}^{0}\right)$ as a reactive agent. The requirement to characterize $\mathrm{Fe}^{0}$ materials in relation to intrinsic reactivity and performance is important for the design and running of $\mathrm{Fe}^{0} / \mathrm{H}_{2} \mathrm{O}$ systems. A deeper knowledge of long-term corrosion of related $\mathrm{Fe}^{0}$ materials at site-specific environments is envisaged to assist in the final design of low-cost, appropriate, and effective $\mathrm{Fe}^{0} / \mathrm{H}_{2} \mathrm{O}$ remediation techniques. A wide range of household and small-size water treatment plants are currently being used for $\mathrm{Fe}^{0}$-based systems, which includes rainwater harvesting methods for the supply of drinking water, decentralized domestic wastewater treatment, urban stormwater treatment, agricultural and industrial wastewater purification, and as philter media for constructed wetlands.

Abdel Rahman and Hung [18] reviewed ionizing radiation technology in the decomposition of bio-refractory organic pollutants and the disinfection of various wastewater effluents. Compared to other disinfection technologies that are not influenced by periodic changes in the effluent constituents, ionizing radiation technology provides cheap, effective, and safer operations and reduces the production of secondary toxic intermediates. Owing to increasingly strict regulatory standards and the upgrading of operating procedures, the operating safety of industrial irradiators has been increased, leading to a reduction in the likelihood of incidents from $10^{-2}$ to $10^{-4} \mathrm{a}^{-1}$.

Author Contributions: Conceptualization, Y.-T.H. and I.A.A.-K.; writing-original draft preparation, H.A.A. and R.O.A.R.; writing-review and editing, M.G.C.-H. and Y.-T.H. All authors have read and agreed to the published version of the manuscript.

Funding: This research received no external funding.

Acknowledgments: The first draft of this paper was prepared by Hamidi Abdul Aziz, who is the corresponding author of this paper. Thanks to all guest editors of this special issue. Thanks to the journal's editors, as well as to the authors who contributed to the Special Issue with their articles. Finally, a special thank goes to the anonymous reviewers, who have made a significant contribution to improving the quality of the articles.

Conflicts of Interest: The authors declare no conflict of interest. 


\section{References}

1. Mukwevho, M.J.; Maharajh, D.; Chirwa, E.M.N. Evaluating the effect of ph, temperature, and hydraulic retention time on biological sulphate reduction using response surface methodology. Water 2020, 12, 2662. [CrossRef]

2. Lange, T.; Schneider, P.; Schymura, S.; Franke, K. The fate of anthropogenic nanoparticles, $\mathrm{nTiO}_{2}$ and $\mathrm{nCeO}_{2}$, in wastewater treatment. Water 2020, 12, 2509. [CrossRef]

3. Haffner, O.; Kučera, E.; Drahoš, P.; Cigánek, J.; Kozáková, A.; Urminská, B. Lemna minor bioassay evaluation using computer image analysis. Water 2020, 12, 2207. [CrossRef]

4. Hu, C.Y.; Liu, Y.J.; Kuan, W.H. pH-dependent degradation of diclofenac by a tunnel-structured manganese oxide. Water 2020, 12, 2203. [CrossRef]

5. Adelodun, B.; Ogunshina, M.S.; Ajibade, F.O.; Abdulkadir, T.S.; Bakare, H.O.; Choi, K.S. Kinetic and prediction modeling studies of organic pollutants removal from municipalwastewater using moringa oleifera biomass as a coagulant. Water 2020, 12, 2052. [CrossRef]

6. Alomar, T.S.; Habila, M.A.; Alothman, Z.A.; AlMasoud, N.; Alqahtany, S.S. Evaluation of groundwater and greywater contamination with heavy metals and their adsorptive remediation using renewable carbon from a mixed-waste source. Water 2020, 12, 1802. [CrossRef]

7. Thaher, R.A.; Mahmoud, N.; Al-Khatib, I.A.; Hung, Y.T. Reasons of acceptance and barriers of house on-site greywater treatment and reuse in Palestinian rural areas. Water 2020, 12, 1679. [CrossRef]

8. Alkhudhiri, A.; Hakami, M.; Zacharof, M.P.; Homod, H.A.; Alsadun, A. Mercury, arsenic and lead removal by air gap membrane distillation: Experimental study. Water 2020, 12, 1574. [CrossRef]

9. Bai, X.; Zhu, X.; Jiang, H.; Wang, Z.; He, C.; Sheng, L.; Zhuang, J. Purification effect of sequential constructedwetland for the polluted water in urban river. Water 2020, 12, 1054. [CrossRef]

10. Azeem, A.; Sun, J.; Javed, Q.; Jabran, K.; Du, D. The effect of submergence and eutrophication on the trait's performance Ofwedelia Trilobata over its congener native Wedelia Chinensis. Water 2020, 12, 934. [CrossRef]

11. Hamid, M.A.A.; Aziz, H.A.; Yusoff, M.S.; Rezan, S.A. Optimization and analysis of zeolite augmented electrocoagulation process in the reduction of high-strength ammonia in saline landfill leachate. Water 2020, 12, 247. [CrossRef]

12. Kim, I.T.; Lee, Y.E.; Yoo, Y.S.; Jeong, W.; Yoon, W.H.; Shin, D.C.; Jeong, Y. Development of a combined aerobic-anoxic and methane oxidation bioreactor system using mixed methanotrophs and biogas for wastewater de-nitrification. Water 2019, 11, 1377. [CrossRef]

13. Mojiri, A.; Kazeroon, R.A.; Gholami, A. Cross-linked magnetic chitosan/activated biochar for removal of emerging micropollutants fromwater: Optimization by the artificial neural network. Water 2019, 11, 551. [CrossRef]

14. Jumat, M.R.; Hong, P.Y. Inactivation and loss of infectivity of Enterovirus 70 by solar irradiation. Water 2019, 11, 64. [CrossRef]

15. Aziz, H.A.; Rahim, N.A.; Ramli, S.F.; Alazaiza, M.Y.D.; Omar, F.M.; Hung, Y.T. Potential use of dimocarpus longan seeds as a flocculant in landfill leachate treatment. Water 2018, 10, 1672. [CrossRef]

16. Ishak, S.A.; Murshed, M.F.; Akil, H.M.; Ismail, N.; Rasib, S.Z.M.; Al-Gheethi, A.A.S. The application of modified natural polymers in toxicant dye compounds wastewater: A review. Water 2020, 12, 2032. [CrossRef]

17. Hu, R.; Yang, H.; Tao, R.; Cui, X.; Xiao, M.; Amoah, B.K.; Cao, V.; Lufingo, M.; Soppa-Sangue, N.P.; Ndé-Tchoupé, A.I.; et al. Metallic iron for environmental remediation: Starting an overdue progress in knowledge. Water 2020, 12, 641. [CrossRef]

18. Abdel Rahman, R.O.; Hung, Y.T. Application of ionizing radiation in wastewater treatment: An overview. Water 2020, $12,19$. [CrossRef] 